\title{
MagyarorszáGi TENDENCIÁK AZ ISKOLAI PREVENCIÓ TERÜLETÉN
}

\author{
PAKSI BORBÁLA
}

ELTE PPK Neveléstudományi Intézet

A tanulmány célja az iskolai prevenciós beavatkozások hozzáférhetősége és az iskolák prevenciós aktivitása vonatkozásában a rendszerváltást követő 30 évben azonosítható hazai tendenciák felvázolása és értelmezése.

A rendelkezésre álló kvantitatív és kvalitatív kutatási eredmények alapján a kilencvenes években lassan beinduló, majd az ezredfordulót követően kezdetben elsősorban a hozzáférés (volumen), később a minőségi dimenziók tekintetében is megmutatkozó kedvező tendenciák mára megtorpantak, sok tekintetben visszalépés tapasztalható. Az utóbbi években mind a prevenció hozzáférhetősége, mind a minőségi fejlesztések tekintetében kedvezőtlen folyamatok, a célpopulációban azonosítható prevenciós szükségletekhez és a nemzetközi tendenciákhoz képest fokozódó hiányjelenségek azonosíthatók.

Kulcsszavak: iskolai prevenció hozzáférhetősége, prevenciós területek, prevenciós célok, prevenció módszerei, magyarországi tendenciák

The aim of the study is to outline and interpret domestic trends in the accessibility of school prevention interventions and prevention activities of schools during the 30 years following the change of regime.

According to the available quantitative and qualitative research results, the favourable tendencies, which started slowly in the nineties and later on at the beginning of the millennium, mainly in the aspects of access (volume) and later in quality, have stopped, in many respects there is a decline. In recent years, unfavourable trends in both access to prevention and quality development, increasing deficits relative to prevention needs identified in the target population and international trends have been identified.

Keywords: school-based prevention, prevention domains, objectives of preventive interventions, prevention methods, Hungarian tendencies

Levelező szerző: Paksi Borbála, ELTE PPK Neveléstudományi Intézet, 1075 Budapest, Kazinczy utca 23-27. E-mail: paksi.borbala@ppk.elte.hu 


\section{Bevezetés}

A $z$ iskola több szempontból is a prevenciós/egészségfejlesztései tevékenység egyik kitüntetett színtere. Az iskolás korosztály számos, egészséget veszélyeztető problémás magatartásmód kialakulása szempontjából döntő fontosságú fejlődési periódusban lévő populáció, azaz Bradshawi (1972) értelemben ${ }^{1}$ az iskolás populációban komparatív szükségletként fokozott prevenciós igény azonosítható. Ehhez a kérdéshez kapcsolódó legfrissebb kutatási adatokat jelen lapszám két írása is részletesen tárgyalja (Elekes 2019; Német-Horváth-Várnai 2019).

A közoktatási intézmények kitüntetett prevenciós szerepét támasztja alá az is, hogy az iskola a személyiségfejlődés, az intézményes szocializáció, az értékek, gondolkodásmódok elsajátítása, alakítása szempontjából érzékeny fejlődési periódusban lévő populáció nagyarányú elérését biztosító színtér (Balázs-Sajgál 1998; Siegel-Bieger 2000; Felvinczi 1998, 2009).

Végül, az iskola társadalmi beágyazottsága, azaz más társadalmi intézményekhez való kapcsolódása, illetve véleményformáló társadalmi potenciálja révén a közvetlenül elért populáción túlmutató prevenciós/egészségfejlesztő hatást is képes gyakorolni (PerjésKovács 2002).

\section{Fogalmi keretek}

A prevenciós fogalomhasználatban korábban meghatározó jelentőségű, a medikális paradigma által definiált, Caplantól (1964) származó klasszikus felosztás (primer, szekunder és tercier prevenció) helyett egyre inkább egy célcsoport fókuszú kategorizáció irányába tolódik el (Mrazek-Haggerty 1994; Robinson et al. 2004). Az osztályozásban bekövetkező szemléletváltás mögött a megelőzés tárgyát jelentő viselkedéssel kapcsolatos paradigmaváltás húzódik meg* „.. a korábbi csoportosítás alkalmas valamilyen patológiás viselkedés kialakulásának leírására, addig kevésbé megfelelő egy komplex emberi viselkedés leírására, különösen akkor, ha az nem is tekinthető diszfunkcionálisnak, vagy patológiásnak" (Brotherhood-Sumnall 2011: 13). A célcsoport alapú osztályozás (Institute of Medicine [IOM] klasszifikáció) a prevenció területén három nagy kategóriát különböztet meg: az általános prevenciót (Universal prevention), a célzott prevenciót (Selective prevention), valamint a javallott prevenciót (Indicated prevention). A prevenciós beavatkozásoknak célcsoport fókuszú osztályozása szerint megkülönböztetett három nagy prevenciós kategórián belül a beavatkozás színtere szerint további alcsoportokat képezhetünk, ezek egyike az iskola (Robertson-David-Rao 2003; Gee-Espiritu-Huang 2006).

\footnotetext{
Bradshaw (1972) a szükségletek három típusát különítette el. Az első típus az érzett vagy kifejezett szükségletek, amelyeket a kliens tapasztal, illetve kifejez. A normatív szükségletek alatt a kezelőszemélyzet vagy szakember által azonosított szükségleteket értjük, míg a komparatív szükséglet a másokkal, a referenciacsoportokkal való összehasonlításból ered. Többnyire ez utóbbi szükséglet áll az általános, illetve célzott prevenció hátterében, $\mathrm{s}$ felfogásunk szerint a prevenció célját jelentő magatartások elterjedtségére vonatkozó populációs vizsgálatok ilyen értelemben a prevenció szükségletmeghatározását is jelentik.
} 


\section{A $z$ iskolák prevenciós aktivitása az elmúlt évtizedekben ${ }^{2}$}

$\mathrm{Az}$ iskolai prevenció területén rutinadatgyüjtésből származó információk egyelőre nem léteznek. ${ }^{3}$ Így az iskolai színtéren zajló prevenciós tevékenységre vonatkozóan csak eseti jelleggel végzett kvantitatív és kvalitatív kutatási információk állnak rendelkezésünkre. A z ezredfordulót követő évtizedben jobb az informáltságunk, ebben az időszakban két, egymással összehasonlítható országos vizsgálat is készült (lásd a későbbiekben), melyek számszerűen láttatják nemcsak az évtized iskolai prevenciós aktivitását, illetve annak változásait, de retrospektív információk révén a korábbi évekre, az iskolai prevenció kezdeteire is valamelyest rálátást adnak. Az ezredforduló második évtizedében nem tudunk ilyen, célzottan az iskolák prevenciós munkájának megismerésére irányuló, országos lefedettségű kvantitatív kutatásokról, azonban részben más témájú kutatások „melléktermékként”, részben kvalitatív kutatások alapján van némi rálátásunk az utóbbi évtized történéseire is.

\section{$A z$ iskolák bekapcsolódása a prevenciós tevékenységbe ${ }^{4}$}

A rendelkezésre álló kutatási adatok alapján az iskolai prevenciós tevékenység beindulása jellemzően a kilencvenes évek végére tehető. Ezt megelőzően mindössze az iskolák 6,5\%-a, többnyire a speciális oktatási intézmények rendelkeztek valamilyen prevenciós tapasztalattal. Az 1998/99-es tanévben azonban annyi intézmény kezdett el valamilyen prevenciós/egészségfejlesztési tevékenységet, mint az azt megelőző mintegy 15 évben összesen. Az 1998 és 2000 közötti években a prevencióba bekapcsolódó iskolák köre 4-6\%-kal bővült évente, de a 2000/2001-es tanévig bezárólag mindössze az intézmények egyötöde szerzett ilyen irányú tapasztalatot. Az iskolai prevenció/egészségfejlesztés a 2001/2002-es tanévben - „Az iskolai egészségfejlesztő-drogmegelőzési tevékenység támogatása" című pályázati program ${ }^{5}$ elindításakor - vett igazán lendületet, ekkor az iskolák további kétötöde kezdett valamilyen prevenciós tevékenységet, aminek eredmé-

2 A „prevenciós aktivitás” fogalomhasználat hátterében az iskolák prevencióval/egészségfejlesztéssel kapcsolatos fogalomhasználatának nagyfokú heterogenitása áll, mely felöleli a szaktanárok óráit, a meghívott előadók által tartott előadásokat, az egészségnapokon történteket, a vetélkedőket, a sportversenyeket, a faliújságot, a védőnők és az iskolaorvosok tevékenységének számtalan formáját (Paksi-Felvinczi-Schmidt 2011).

3 A KSH Nemzeti Statisztikai Koordinációs Testület Kábítószer-statisztika fejlesztésére irányuló munkabizottsága keretében 2018-ban történt ez irányú kezdeményezés. A munkabizottság úgy látta, hogy egy, az Oktatási Hivatal által müködtetett Köznevelés Információs Rendszer (KIR) intézményi és tanulói szintű kérdőíveiben elhelyezett egészségfejlesztési/prevenciós tevékenységgel kapcsolatos kérdésblokk hiánypótló információkkal szolgálhatna az iskolai prevenció elterjedtségére s alapvető jellemzőire vonatkozóan, és javaslatot tett a KIR ez irányú bővítésére. Azonban a javaslat egyelőre nem nyert befogadást.

4 Itt, valamint a következő, az iskolai prevenció expanzív időszakával foglalkozó részben egy 2004 tavaszán, a magyarországi közoktatási intézmények (általános iskolák, gimnáziumok, szakközépiskolák, illetve szakiskolák) 263 intézményre kiterjedő országos reprezentatív mintáján készült kutatás (Paksi-FelvincziSchmidt 2011) eredményeit foglaljuk össze. A kutatás célja az iskolák prevenciós tevékenységének megismerése volt.

5 Az ifjúsági ügyekért felelős minisztérium és az oktatási tárca 2001-től évente pályázatot írt ki az iskolai egészségfejlesztési, egészségnevelési és drogprevenciós feladatok támogatására. A pályázat lehetővé tette, hogy az alap- és középfokú nevelési-oktatási intézmények 5-12. évfolyamán tanulók - évente átlagosan 100-130 ezer fó - részt vegyenek egészségfejlesztési és drogprevenciós foglalkozásokon (Simonyi 2012). 


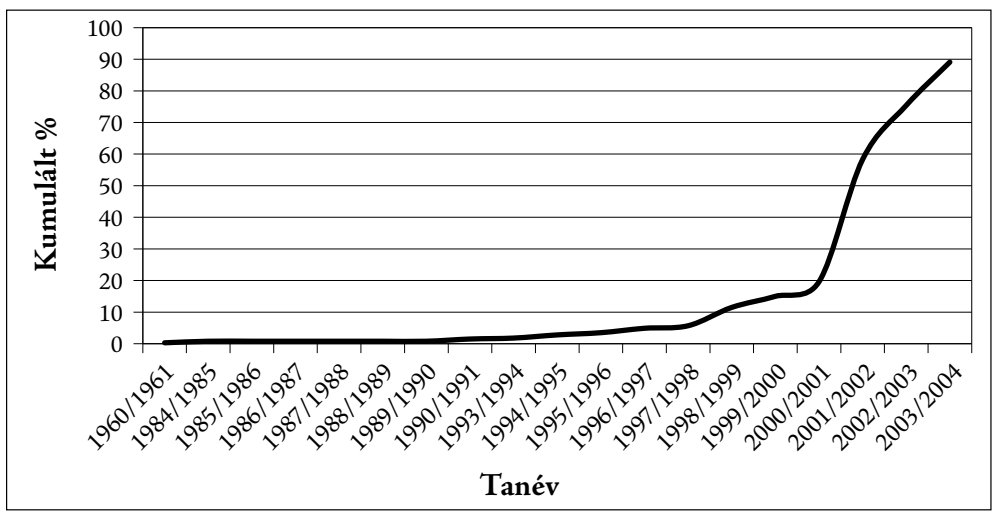

1. ábra: A közoktatási intézmények bekapcsolódása az iskolai prevenciós/egészségfejlesztő tevékenységbe (magyarországi közoktatási intézmények országos reprezentatív mintáján $[N=263$ iskola $])^{6}$

(Paksi-Felvinczi-Schmidt 2011)

nyeként összességében az iskolák közel 60\%-a már túl volt az első prevenciós tapasztalaton. Ezt követően 2002/2003-ban az iskolák további hatoda, majd a 2003/2004-es tanévben a még „érintetlen” intézmények háromötöde kapcsolódott be a prevenciós/ egészségfejlesztési munkába (1.ábra).

Talán az iskolai prevenció érdemi beindulásának „Az iskolai egészségfejlesztő-drogmegelőzési tevékenység támogatása"című pályázati program indulásával való egybeesése alapján nem meglepő, hogy a vizsgált prevenciós területek (mentálhigiéné, biztonság, környezet, növekedés/változás/szexualitás, családi élet, legális/illegális szerhasználat, testi higiéné, fizikai aktivitás, táplálkozás, integrált holisztikus megközelítés) közül az első prevenciós intervenciók során a legális/illegális szerhasználat volt a leggyakrabban (63,3\%) megcélzott terület. Az iskolai prevenciós beavatkozások közel kétharmada dolgozott drogprevenciós céltételezéssel (is). Ehhez képest a további legnépszerübb tematikák (táplálkozás, mentális, illetve testi higiéné) is fele ekkora gyakorisággal fordultak elö.

\section{$A z$ iskolai prevenció expanzív idöszaka}

$\mathrm{A} z$ iskolák prevenciós tevékenységbe való bekapcsolódásának dinamikája (lásd 1. ábra), az egyes tanévekben prevenciós aktivitást mutató iskolák aránya és a beavatkozások tartalmi jellemzői alapján a 2001 és 2004 közötti periódust az iskolai prevenció expanzív időszakának tekinthetjük.

Míg az ezredfordulón csak az iskolák egyötöde rendelkezett valamilyen prevenciós tapasztalattal, az időszak végére már tíz iskolából kilenc. Ebben az időszakban nemcsak a már prevenciós tapasztalattal rendelkező iskolák aránya növekedett, de az egyes tanévekben prevenciós aktivitást mutató iskolák aránya is folyamatosan és egyenletesen emelkedett (2. ábra).

A „Mikor végzett az iskola először prevenciós tevékenységet?” kérdésre adott válaszok, az iskolák kumulált százalékában kifejezve. 


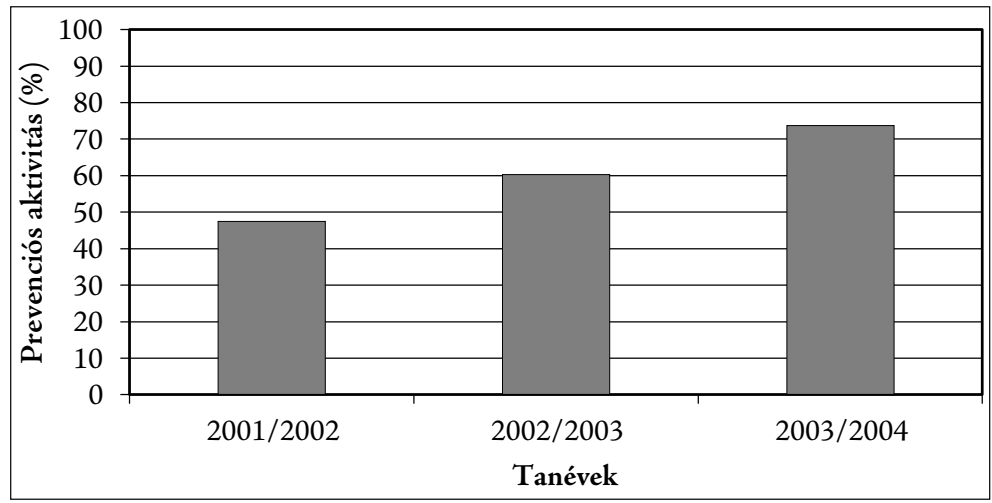

2. ábra: Az egyes tanévekben prevenciós aktivitást mutató iskolák aránya az ezredfordulót követő években (\%) (Paksi-Felvinczi-Schmidt 2011)

Tartalmi/minőségi változások ugyanakkor kevéssé voltak tapasztalhatók ebben az időszakban: a megcélzott területek, a prevenciós megközelítések, az alkalmazott módszerek, vagy az iskolák/pedagógusok bevonódása tekintetében egyaránt meglehetős stabilitás jellemezte az évezred első éveit. A különböző programjellemzők közül egyedül a programok időtartama tekintetében mutatkozott az időszak végére valamelyest a nemzetközi ajánlásoknak irányába való elmozdulás.

A prevenciós beavatkozások tartalmi jellemzőinek változatlansága egyrészt azt jelentette, hogy nem voltak megfigyelhetők az olyan, a szakma elvárásait inkább leképező irányba való elmozdulások, mint az interaktív oktatási módszerek alkalmazása (Tobler 1997; Tobler-Stratton 1997), vagy a normatív hiedelmek megváltoztatására irányuló (Flay 2000; Taylor 2000; Reis et al. 2000), illetve a szociális befolyásolást, a társas kompetenciákat növelö tartalmak (Hansen 1992; Dusenbury-Falco 1995; Paglia-Room 1999; Tobler et al. 2000; Tobler 2001; Soole-Mazerolle-Rombouts 2005) térhódítása. Hasonlóképpen nem tapasztaltunk a komplex, integrált szemléletü programok irányába való elmozdulást sem. Ugyanakkor nem csökkent az ismeretátadásra fókuszáló programok aránya, holott a szakirodalom ezeket a beavatkozásokat már ebben az időszakban sem tekintette hatékony megközelítéseknek (Werch-Owen 2002; Soole-Mazerolle-Rombouts 2005). Az ezredfordulót követő években hasonló tendenciák az Unió számos tagállamában voltak tapasztalhatók: sok helyen a döntéshozók és a szakemberek gyakran továbbra is azon megközelítéseket részesítették előnyben, melyeket a korszerü szakirodalom nem tartott hatékonynak (EMCDDA 2005).

\section{$A z$ iskolai prevenció minőségi fejlödésének beindulása}

$\mathrm{A} z$ iskolai prevenció expanzív időszakát követően a közoktatási intézmények prevenciós aktivitása stabilizálódni látszott: Az ezredforduló első évtizedének második felében az

A fejezet hátterét egy 2009 tavaszán, a magyarországi közoktatási intézmények országos reprezentatív mintáján, az előző, 2004-es kutatással megegyező módszertannal készült kutatás eredményei képezik (Paksi 2010; Paksi-Felvinczi-Schmidt 2011). A kutatás célja az iskolák prevenciós tevékenységében történt változások nyomon követése volt. A nettó minta összesen 133 intézményt és 207 feladatellátási helyet tartalmazott. 


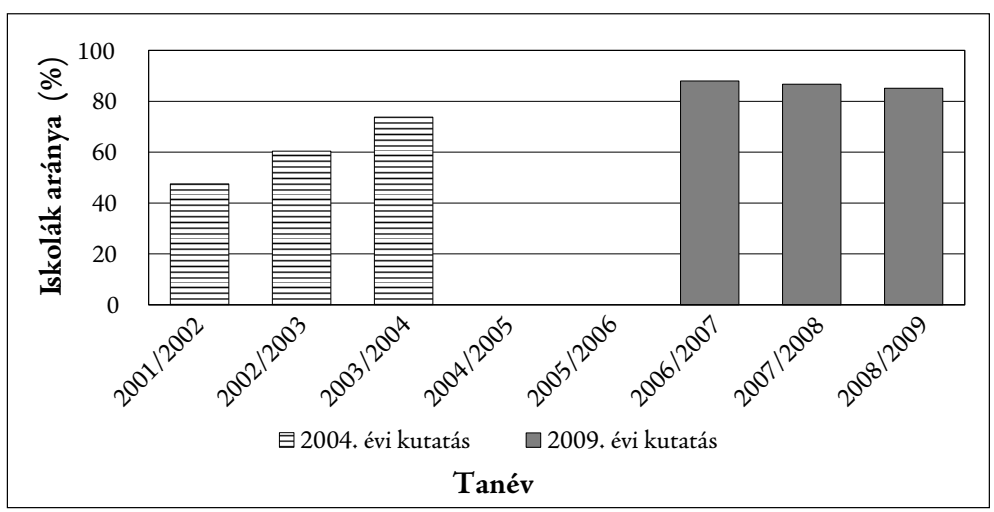

3. ábra: Az egyes tanévekben prevenciós aktivitást mutató iskolák aránya az ezredforduló utáni első évtizedben (\%) (Paksi-Felvinczi-Schmidt 2011)

egyes tanévekben az iskolák 85-88\%-ában történt valamilyen prevenciós beavatkozás. A közoktatási intézményekben tanuló diákok országos létszáma ${ }^{8}$ és a prevenciós beavatkozásokon való - az iskolaigazgatók által becsült - tanulórészvételi arány átlaga alapján azt mondhatjuk, hogy ezekben az években évente átlagosan mintegy 800 ezer diák vett részt az iskolai színtéren valamilyen ${ }^{9}$ prevenciós beavatkozásban.

Ebben az időszakban a prevenciós tevékenység rendszeressége is jelentősen növekedett: míg az ezredforduló első éveiben az iskolák körülbelül egyharmadában volt minden évben prevenció, az évtized második felében tízből nyolc iskolában rendszeressé váltak a beavatkozások. A prevenció rendszeressé válása minőségi változásra utaló tendenciaként értelmezheto, tekintettel arra, hogy a szakirodalom szerint (Soole-MazerolleRombouts 2005) a beavatkozások hatásosságát növeli, ha egy éven belül ismétlésre vagy a beavatkozás bizonyos elemeinek felfrissítésére sor kerül.

$\mathrm{A} z$ iskolai prevenciós beavatkozások időtartamában szintén kedvező változásokra utaló tendenciák jelentkeztek: az évtized második felében a korábban jellemző 3-5 órás intervenciók helyett a 10-20 órás beavatkozások fordultak elő legnagyobb arányban.

Ebben az időszakban az iskolákban végzett prevenciós munka által felölelt területek is némileg átstrukturálódtak. Míg 2001 és 2004 között a legális/illegális szerhasználat volt a dominánsan megcélzott területe az iskolai prevenciónak - a programok fele-háromötöde dolgozott ezekben az években drogprevenciós céltételezéssel (is) -, az évtized második felében a drogprevenciós programokkal azonos arányban szerepeltek az iskolai színtéren a mentálhigiénével, valamint a táplálkozással foglalkozó prevenciós intervenciók. A vezető témák átstrukturálódása úgy következett be, hogy a drogtematika szerepe az évtized első felének előfordulási átlagához képest csak kismértékben csökkent, míg a mentálhigiénével, illetve a táplálkozással foglalkozó programok előfordulása jelentősen növekedett. Ezek mellett még kétharmados biztonsággal azt mondhatjuk, hogy növekedett néhány olyan, korábban alacsonyan priorizált terület szerepe, mint a környe-

8 http://www.ksh.hu/docs/hun/xstadat/xstadat_hosszu/h_wdsi001b.html [Letöltve: 2019. 09. 01.]

9 Ezekben az években kiegyenlítettebbé vált a prevenció során megcélzott területek eloszlása: míg az első prevenciós beavatkozások alkalmával, illetve az expanzív fejlődés időszakában - mint jeleztük - a megcélzott területek közül kiemelkedett a legális/illegális szerhasználat, ebben az időszakban felzárkóztak mellé a mentálhigiénével, valamint a táplálkozással foglalkozó prevenciós intervenciók. 


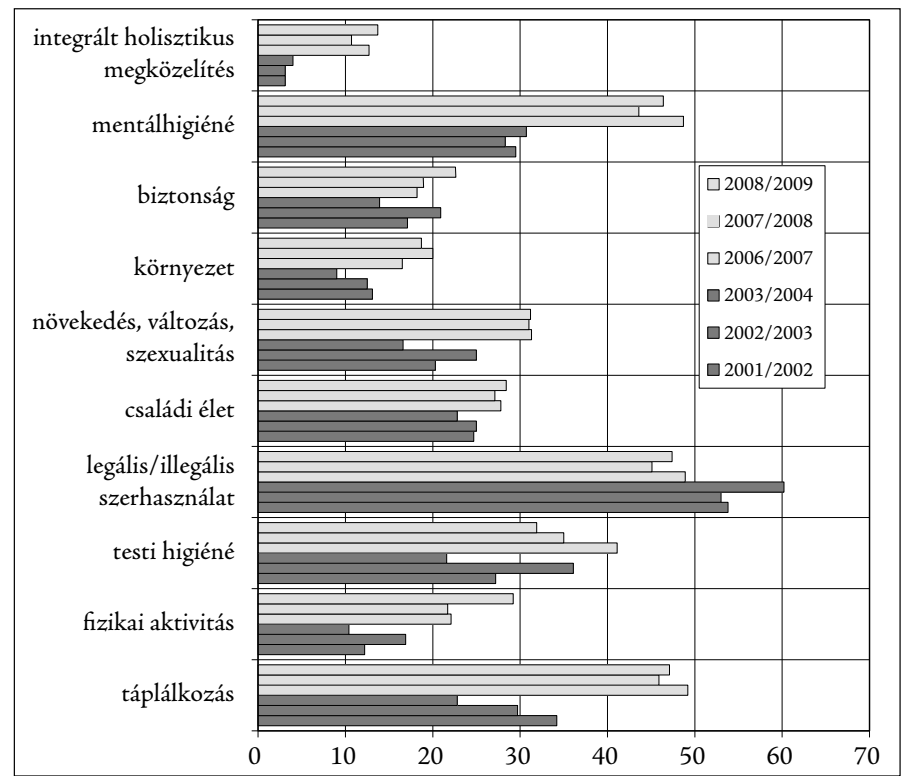

4. ábra: A különböző prevenciós területek megjelenése az iskolai prevenciós beavatkozásokban 2001 és 2003, valamint 2006 és 2009 között (az adott évben prevenciót végző iskolák százalékában, iskolánként több választ megengedve) (\%) ${ }^{10}$ (Paksi 2010)

zet, biztonság, növekedés/változás/szexualitás, illetve szignifikánsan nagyobb arányban fordul elő a felölelt területek között a „fizikai aktivitás”, illetve az integrált holisztikus megközelítés. Az integrált holisztikus megközelítés szerepének növekedése, illetve az egy-egy beavatkozás során megcélzott területek számának emelkedése azt is jelzi, hogy az iskolai beavatkozások ebben az időszakban kezdtek elmozdulni a komplexebb beavatkozások irányába (4. ábra).

Ezekben az években kedvező irányú elmozdulások jelei mutatkoztak a beavatkozások tartalmi elemei tekintetében is. Csökkent az ismeretátadásra koncentráló megközelítés, s növekedett a korszerü szakirodalom alapján priorizált, a társas kompetenciák növelésére, illetve a normatív hiedelmek megváltoztatására irányuló tartalmak előfordulási aránya. A hazai prevenciós megközelítésekben megjelenő tendencia megegyezett az Európában általában tapasztalt hangsúlyeltolódás irányával: „2007-ben a prevenciós tevékenységek leggyakoribb célkitűzése a jelentések szerint az életvezetési készségek kialakítása volt (28 országból 12-nél), míg 2004-ben az országok fele (26-ból 13) a tudatosság fokozását és a tájékoztatást nevezte meg fó célként" (EMCDDA 2008: 28). Ugyanakkor a magyarországi iskolákban zajló prevenciós beavatkozások több mint felében az időszak végén is jelen voltak ismeretátadásra vonatkozó célkitűzések, s a korszerü szakirodalom alapján priorizált, a társas kompetenciákat növelő tartalmak előfordulási aránya továbbra is csak felére volt tehető az ismeretátadási tartalmak előfordulásának (5. ábra).

10 Tekintettel arra, hogy az ábra az expanzív és a minőségi változásokkal jellemezhető időszak eltéréseit kívánja bemutatni, így itt - és a következő diagramon is - a prevenció szempontjából eltérő két periódust jelöltük elkülönülő színekkel, az egyes évek a sávok sorrendje alapján azonosíthatók. 


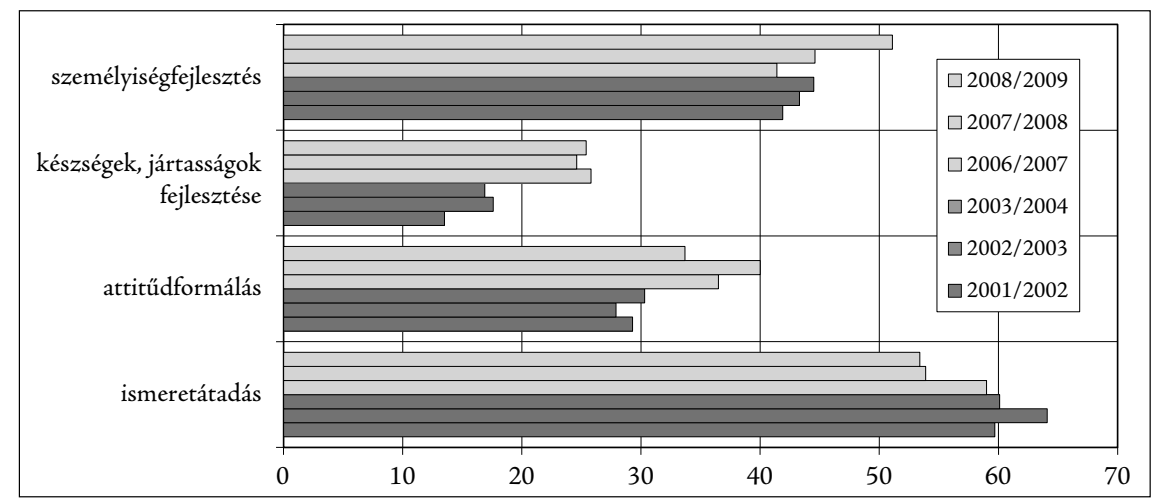

5. ábra: A különböző prevenciós megközelítések/irányzatok előfordulási gyakorisága az iskolai prevenciós beavatkozásokban 2001 és 2003, valamint 2006 és 2009 között (az adott évben prevenciót végző iskolák százalékában, iskolánként több választ megengedve) (Paksi 2010)

Összességében tehát azt mondhatjuk, hogy a magyarországi közoktatási intézményekben zajló prevenciós tevékenységek tartalmi jellemzői tekintetében az ezredforduló első évtizedének második felében kedvező, a korszerű prevenciós tartalmak irányába mutató elmozdulások indultak meg, mindazonáltal a hazai beavatkozások összetétele sok tekintetben 2009-ben is elmaradt a szakirodalom szerint kívánatos, illetve a nemzetközi gyakorlat alapján (EMCDDA 2008) korszerűnek minősíthető programstruktúrától.

\section{$A z$ iskolai prevenciós tevékenység visszaszorulása}

$\mathrm{A} z$ iskolai színtéren zajló prevenciós tevékenységre vonatkozóan - mint azt a fejezet bevezetőjében említettük - 2009-ben készült az utolsó országos kvantitatív adatokkal szolgáló, célzottan erre a témára fókuszáló kutatás (Paksi 2010). Az elmúlt 10 évre jellemző információhiány már önmagában is jelentős kockázati tényezőt jelent a kedvezőtlen irányú változások tekintetében. Hiszen a prevenció helyzetét szisztematikusan leíró, strukturált információk - rendszer szinten és az egyes iskolák szintjén is - elengedhetetlenek a fejlesztendő területek azonosításához, a fö irányok meghatározásához, a beavatkozások valóságra reflektáló tervezéséhez.

Ezen információhiánnyal jellemezhető időszakra vonatkozóan az iskolai prevenciós tevékenység egyik fó területének, a drogprevenciós beavatkozásoknak a helyzetébe ad betekintést egy 2012-ben (Paksi-Magi 2013), illetve egy 2015-ben készült (KCKT 2015) kvalitatív kutatás, ${ }^{11}$ továbbá általában a prevenciós beavatkozások (bármilyen színtéren folyó általános, célzott vagy javallott intervenciók) hozzáférhetősége vonatkozásában információval szolgál még a Nemzeti Drogellenes Stratégia (NDS 2013) 2017-ben

11 Mindkét kutatás fókuszcsoportos adatgyűjtési módszer alkalmazásával készült. A vezérfonal összeállításának alapjául az EMCDDA általános és célzott prevencióval kapcsolatos strukturált kérdőívei szolgáltak A fókuszcsoport résztvevői a drogmegelőzés területén (is) tevékenykedő szakemberek voltak. A 2012-es kutatásban öt fókuszcsoportban összesen 35 szakértő vett részt, a 2015-ös kutatásban pedig 1 fókuszcsoport készült 22 szakértő részvételével. 
készült kvalitatív értékelése (KCKT 2018) ${ }^{12}$ is. A 2012-es és a 2015-ös kutatásokban a részt vevő szakemberek percepciói alapján azt mondhatjuk, hogy a drogprevencióhoz való hozzáférés az iskolai színtéren korlátozott: azaz több mint néhány iskolában hozzáférhető, de az iskolák többségében nincs. 2017-ben általában a prevenció hozzáférésével kapcsolatban az NDS értékelésében részt vevő szakemberek ennél is rosszabbnak ítélték a helyzetet: egyöntetűen azt az álláspontot képviselték, hogy a különböző prevenciós beavatkozások az országban általában mindössze néhány helyen müködnek, a legtöbb helyen nem hozzáférhetőek (6. ábra).

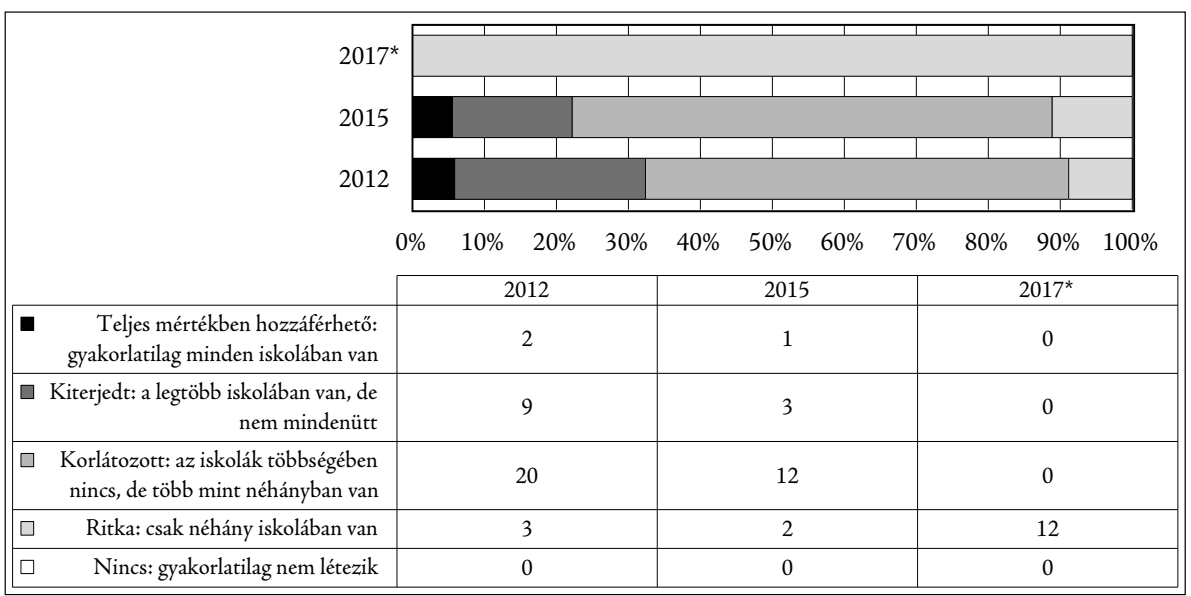

6. ábra: A kvalitatív kutatásokban részt vevő szakértők véleménye 2012-ben, 2015-ben az iskolai drogprevenció, valamint 2017-ben általában a prevenció hozzáférhetőségéről (fö) (Paksi-Magi 2013; KCKT 2015, 2018).13

*A 2017-es válaszok általában a prevenciós beavatkozásokra vonatkoznak

A 6. ábrán látható, korlátozott elérhetőségre vonatkozó vélemények esetenként 2012 ben és 2015-ben sem csak a hozzáférhetőség mennyiségi értékelését jelentették, hanem a prevenciós tevékenység minőségével kapcsolatos kritikát is megfogalmaztak a hozzáféréssel kapcsolatos véleményükben a szakértők: „...én azért mondom, hogy korlátozott, mert lehet, hogy biába van száz iskolából mind a százban program, de hogy az nem elvárbató színvonalú..." (Kulturális területen dolgozó, drogprevencióval 4 éve foglalkozó szervezet képviselöjének véleménye egy 2012-ben készült fókuszcsoportban.) (Paksi-Magi 2013:16), illetve „...korlátozottan jelen van, hiszen jelen van, de egyre kevesebb, egyre rosszabb minöségü programok, egyre kevesebb idöben érjük el a gyerekeket, akkor most miröl beszéljünk." (Részlet egy 2015-ös fókuszcsoportból.) (KCKT 2015: 39.)

12 A Nemzeti Drogellenes Stratégia értékelését a Kábítószerügyi Civil Koordinációs Testület (KCKT) végezte, szintén fókuszcsoportos módszer alkalmazásával. A prevenciós beavatkozások értékelésében részt vevő szakemberek száma 16 fö volt.

13 Az ábrán kvalitatív kutatási adatok szerepelnek, ahol a válaszok összetételét nem \%-os megoszlásban, hanem csak a résztvevő személyek válaszaiban megjelenő tendenciát érzékeltetve szokás (és indokolt) megjeleníteni. Jelen esetben - és a következő ábrán is - a különbözö időpontokban készült kutatások eredményeinek „együtt láttatása” miatt választottuk a \%-os és természetes mértékegységben (föben) való párhuzamos megjelenítést. 


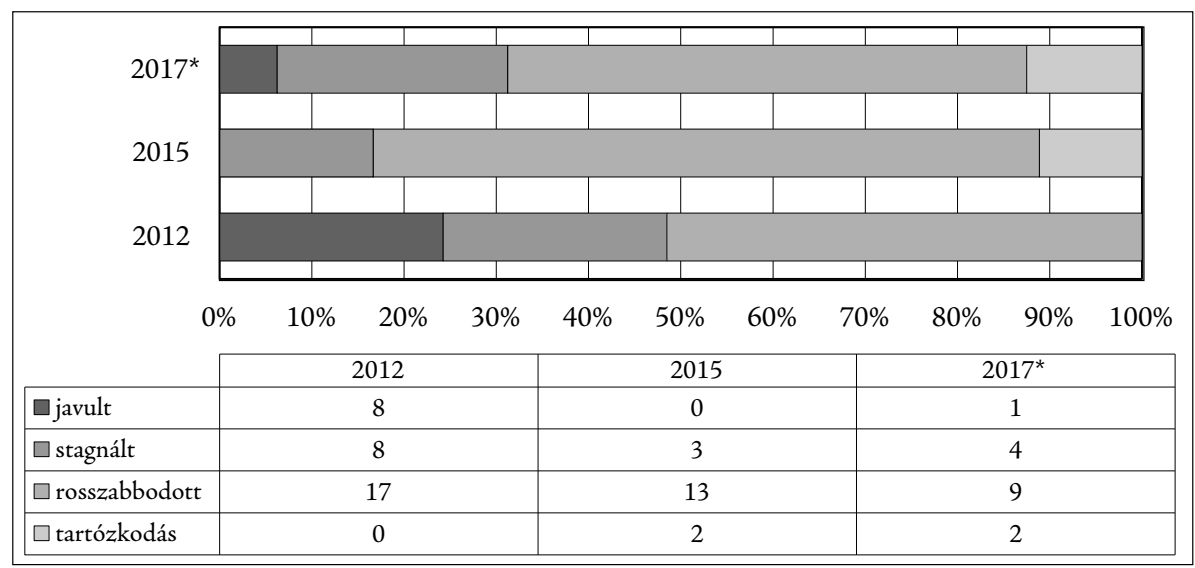

7. ábra: A kvalitatív kutatásokban részt vevő szakértők véleménye az iskolai drogprevenció hozzáférhetőségének alakulásáról (fö) (Paksi-Magi 2013; KCKT 2015, 2018).

*A 2017-es válaszok általában a prevenciós beavatkozásokra vonatkoznak

Bár a hozzáférhetőségre vonatkozó kvalitatív adatok csak nagyon korlátozottan hasonlíthatók össze a korábbi kvantitatív adatokkal, de talán nem túlzás azt feltételeznünk, hogy a 2012 és 2017 közötti vélemények jelentős visszalépést jeleznek a 2006 és 2009 közötti helyzethez képest, amikor az iskolák $80 \%$-ában rendszeresen, minden évben történt valamilyen beavatkozás. Negatív tendencia bontakozik ki - a kvalitatív adatok nem általánosítható volta miatt egymással szintén csak korlátozottan összevethető - egyre kisebb hozzáférésről beszámoló szakértői percepcióik alapján is. De nemcsak ezen korlátozott érvényességü összehasonlítások alapján mutatkozik az iskolai prevenció visszaszorulása. Ezzel összhangban, az egyes kutatások során a prevenció hozzáférhetőségének tendenciájára vonatkozó szakértői vélemények is egyértelműen kedvezőtlen változásokat jeleztek (7. ábra).

$\mathrm{A} z$ iskolai prevenció struktúrája, az alkalmazott modalitások előfordulása tekintetében szintén rendre kedvezőtlen látleletet adtak a kutatásban részt vevő szakértők. Bár a hazai prevenció összetétele mindig elmaradt a szakirodalom alapján kívánatos struktúrától, de - mint fentebb bemutattuk - az ezredforduló első évtizedének második felében a kutatások kedvező elmozdulásokat jeleztek: megszűnni látszott az ismeretátadásra koncentráló megközelítés dominanciája, s növekedett a korszerü szakirodalom által alátámasztott, a társas kompetenciákat növelő, vagy normatív hiedelmek megváltoztatására törekvő tartalmak előfordulási aránya. Az utóbbi egy évtized kvalitatív vizsgálatok által lefedett időszakában az iskolai prevenció különböző modalitásai között a területen dolgozó, a kutatásokban részt vevő szakemberek leginkább a kötelező adminisztratív elöírásokban szereplő, illetve az iskola számára kisebb költséget jelentő megoldások (dohányzási tilalom, információs napok, rendőrök által tartott előadások) dominanciáját érzékelik. Ugyanakkor csak korlátozottan vagy ritkán találkoznak a szakirodalom alapján kívánatosnak tekinthető, bizonyítékkal támogatott beavatkozásokkal. Mint azt a 8. ábrán láthatjuk, Európa legtöbb országában hasonló a különböző modalitások preferenciasorrendje, azonban míg néhány bizonyítékon alapuló beavatkozás (pl. készségfejlesztő programok, szülők számára szervezett programok) az iskolák többségében hozzáférhető a legtöbb európai országban (EMCDDA 2015), nálunk ezek 


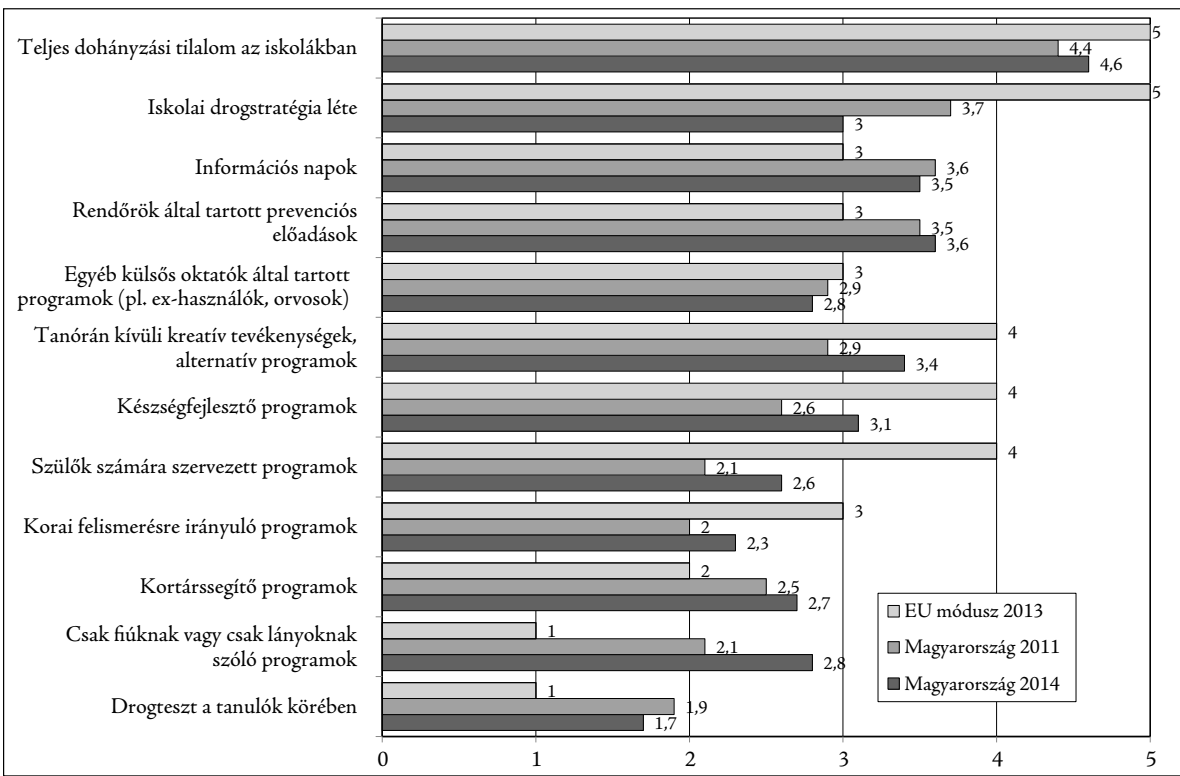

8, ábra: A különböző iskolai drogprevenciós megoldások hozzáférhetősége Magyarországon és Európában (hazai vélemények átlagai és az uniós országok átlagainak módusza) (KCKT 2015; EMCDDA 2015) ${ }^{14}$

a beavatkozások az utóbbi években az iskolák többségében csak „korlátozottan” vagy „ritkán” elérhetők. Ugyanakkor bizonyos, kevésbé korszerü, és területen dolgozó szakemberek által is kritikával illetett megoldások (pl. az információs napok, rendőrök által tartott prevenciós előadások) ma már az európai országok többségében a magyarországi jelenlétükhöz képest kevésbé általánosnak mondhatók (8.ábra).

A fenti, az iskolák prevenciós aktivitásának visszaesésére vonatkozó kvalitatív kutatási tapasztalatokat megerősíti egy 2015-ben, más témában készült, de „melléktermékként” az iskolák aktuális prevenciós aktivitásáról számszerü adatokkal szolgáló kvantitatív kutatás ${ }^{15}$ (Paksi-Magi-Demetrovics 2017). A kutatás adatai szerint a 2012 és 2015 közötti tanévekben átlagosan a 7-14 évfolyamos osztályok mintegy felében folyt valamilyen prevenciós munka, ami a prevenciós aktivitás volumenének az ezredforduló utáni években jellemző szintre való visszaesését jelentette.

Tehát a kvalitatív kutatásokhoz hasonlóan, a kvantitatív adatok is egyértelműen az iskolák prevenciós tevékenységének visszaesését mutatják. Ugyanakkor azt is látjuk, hogy a kvantitatív adatokban jelzett elterjedtséghez (minden második iskola végez valamilyen prevenciós tevékenységet) képest az ugyanezen időben készült kvalitatív vizsgátokban

14 Az ábrán a következő válaszok átlagai láthatók: 5 - Teljes mértékben: gyakorlatilag minden iskolában van; 4 -Kiterjedt: a legtöbb iskolában van, de nem mindenütt; 3 - Korlátozott: az iskolák többségében nincs, de több mint néhányban van; 2 - Ritka: csak néhány iskolában van; 1 - Nincs: gyakorlatilag nem létezik.

15 A kutatás célja a Szerencsejáték Zrt. társadalmi felelősségvállalási programjához kapcsolódóan, a fiatal 14-24 év közötti populáció körében tervezett, a szerencsejáték tevékenység kockázatainak csökkentésére irányuló prevenciós tevékenység szakmai megalapozása volt. Az adatfelvétel a 7-14 éves diákok országos reprezentatív mintáján készült, 200 osztály részvételével. A drogprevencióval kapcsolatos kérdéseket a kiválasztott osztályok osztályfönökeivel vettük fel. 


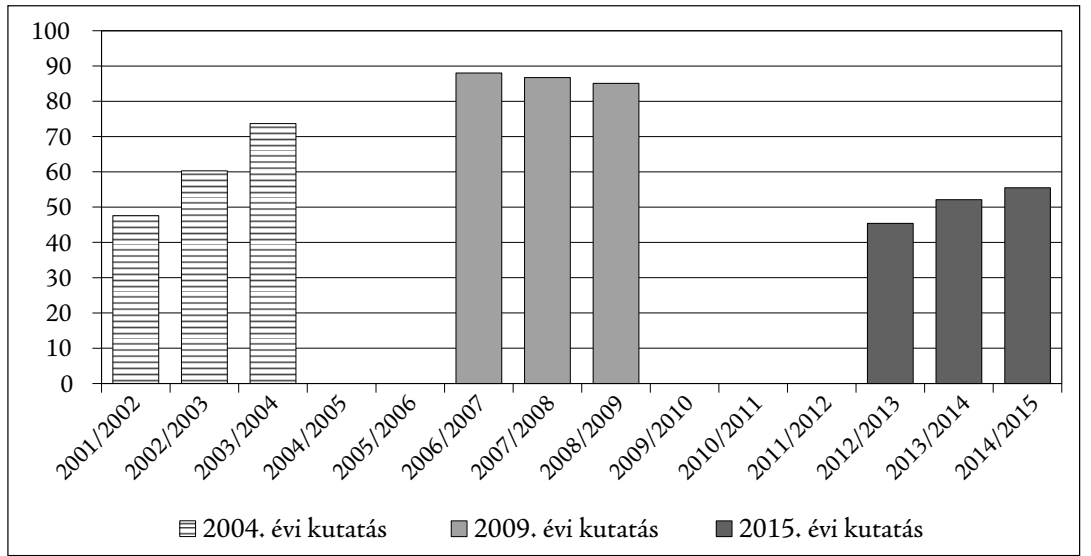

9. ábra: A prevenciós aktivitást mutató iskolák aránya a különböző időszakokban (Paksi-Magi-Demetrovics 2017)

dominánsan megfogalmazott korlátozott hozzáférhetőség (az iskolák többségében nincs, de több mint néhányban van) az iskolai színtér alacsonyabb részvételét jelzi. Ne felejtsük el azonban, hogy a kvalitatív adatok csak az iskolák drogprevenciós tevékenységére vonatkoztak, mely ugyan a prevenciós programok „beindulása” óta meghatározó területe volt a magyarországi iskolai prevenciónak (lásd 4. ábra), de 2006-2009 között már csak az iskolák prevenciós aktivitásának 45-50\%-át tették ki, s a 2015-ös adatok szerint pedig 25-30\%-ra szorult vissza ez a tematika (10. ábra). Ha ezt is figyelembe vesszük, akkor az egyes években drogprevencióval (is) foglalkozó iskolák/osztályok aránya a

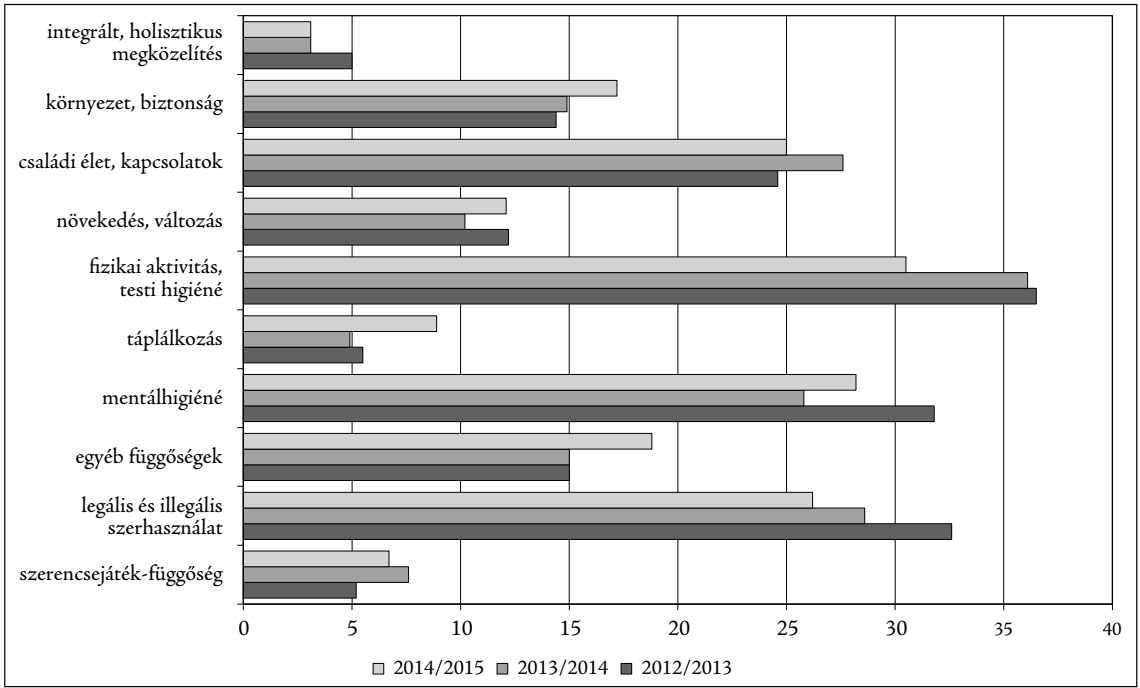

10. ábra: A különböző prevenciós területek megjelenése az iskolai prevenciós beavatkozásokban 2012 és 2015 között (az adott évben prevenciót végzö iskolák százalékában, iskolánként több választ megengedve) (\%) (Paksi-Magi-Demetrovics 2017) 
magyarországi iskolákban valóban mindössze 15\% körül mozog, ami harmonizál a kvalitatív kutatások során a drogprevenció hozzáférhetőségével kapcsolatban kapott szakértői visszajelzésekkel, azzal, hogy az iskolák többségében nincs, de több mint néhányban van drogprevenciós beavatkozás. A különböző forrásból származó, eltérő információk tehát azonos irányba, az iskolák prevenciós szerepvállalásának csökkenése irányába mutatnak.

\section{Záró gondolatok: Az iskolák prevenciós aktivitásában tapasztalható változások hátterében álló tényezők}

Mint azt az iskolák prevenciós tevékenységbe való bekapcsolódásával foglalkozó részben láthattuk, a közoktatási intézmények első prevenciós beavatkozásainak közel kétharmada a legális/illegális szerhasználattal (is) foglalkozott (Paksi-Felvinczi-Schmidt 2011). A prevenciós/egészségfejlesztő munkába való bekapcsolódásának trendjét összevetve az intervenciók dominánsan megcélzott területére, a drogprobléma alakulására vonatkozó epidémiai adatokkal (lásd az 11. ábrán az oszlopdiagram és a folyamatos vonaldiagramok viszonyát), azt láthatjuk, hogy az iskolák prevenciós tevékenysége megkésve reagált a beavatkozások meghatározó részének tematikáját képező legális/illegális szerhasználat epidémiájára, a középiskolások drogérintettségének alakulására. A középiskolás populációban végzett drogepidemiológiai vizsgálatok (Elekes-Paksi 1996, 2000) már a kilencvenes évek második felében - regionális és helyi jellegü vizsgálatok alapján vélhetően 1997-1998-tól - a fiatalok drogérintettségének ugrásszerü növekedését jelezték. Erre az epidémiai kihívásra a közoktatási intézmények csak 3-4 éves késéssel, a célzott pályázati támogatások beindulásával kezdtek reagálni. Az iskolák prevenciós tevékenysége tehát elsősorban nem a szükségletekhez alkalmazkodó módon, sokkal inkább a források, elsődlegesen a támogatási rendszer alakulásának függvényében történt. Ez nemcsak a prevenciós tevékenység dinamikájában, de a tematikájában, az átlagosnál nagyobb mértékben támogatott drogtematika dominanciájában is megjelent.

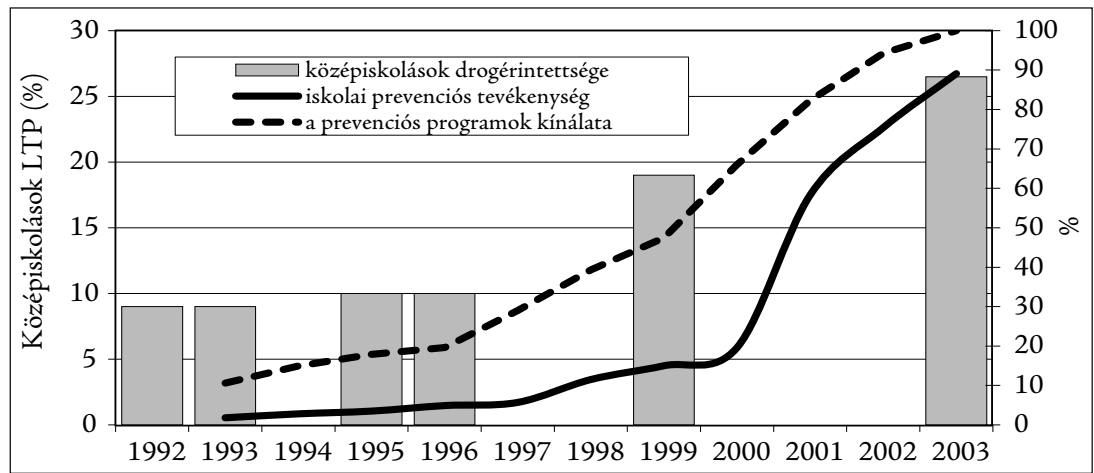

11. ábra: $A z$ iskolák prevenciós aktivitásának (az iskolák százalékában, a jobb oldali tengelyen ábrázolva), a prevenciós szolgáltatások megjelenésének (a 2003-ban jelen lévő programok százalékában, szintén a jobb oldali tengelyen ábrázolva), valamint a középiskolások drogérintettségének (a 10. évfolyamos diákok körében a biztosan droghasználati célú szerhasználat életprevalencia értéke, a bal oldali tengelyen ábrázolva) alakulása (Paksi-Felvinczi-Schmidt 2011) 


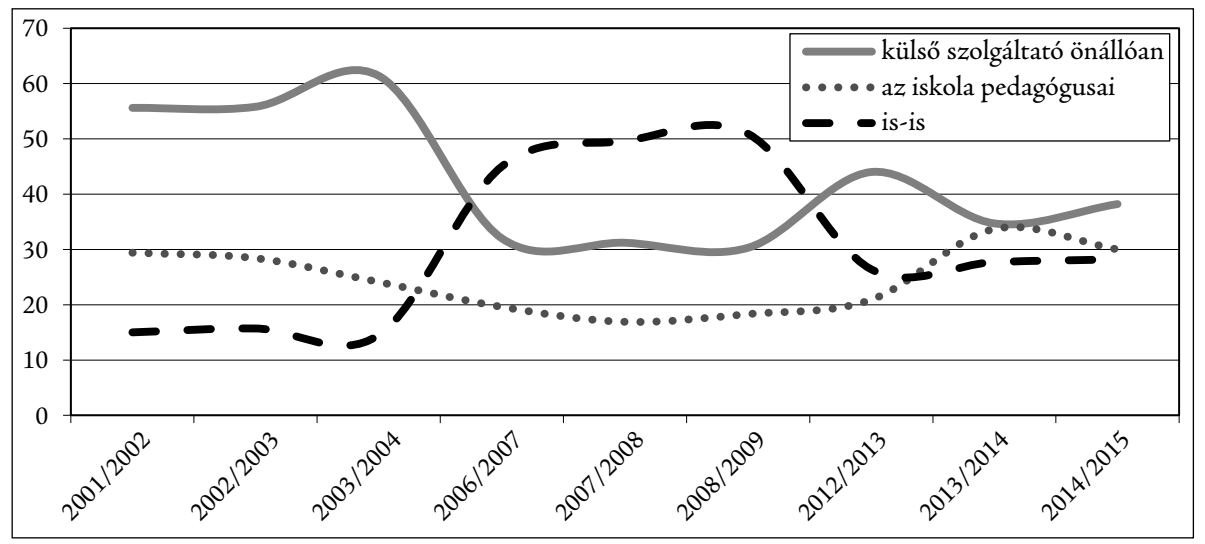

12. ábraः Kik végezték a prevenciós tevékenységet az iskolában? (a prevenciót végző iskolák százalékában kifejezve) (Paksi-Magi-Demetrovics 2017)

A közoktatási intézmények prevenciós aktivitásának trendjét az iskolai drogprevenciós színtéren jelen lévő szolgáltatások kínálatának trendjével (Paksi-Demetrovics 2005) összevetve pedig azt láthattuk, hogy az iskolák a prevenció alakításának kevéssé aktív, azt alakító szereplői voltak, prevenciós aktivitásuk inkább kínálatkövetően, mintsem azt meghatározó módon alakult (lásd a 11. ábrán a szaggatott és a folyamatos vonaldiagramok viszonyát).

$\mathrm{Az}$ iskoláknak - a prevenciós tevékenység tekintetében - kevéssé aktív, a külső prevenciós szolgáltatásokat inkább lekövető magatartását erősíti az a kutatási tapasztalat is, hogy az iskolák - változó mértékben ugyan - az iskolai prevenció beindulásától kezdve a legutóbbi időkig elsősorban külső szolgáltatók bevonásával (csak külső szolgáltatás megrendelésével vagy külső szolgáltatókkal közösen) végeznek prevenciós tevékenységet (lásd 12. ábra).

$\mathrm{A} z$ iskolák prevenciós tevékenységnek a prevenciós szükségletekre, illetve prevenciós szakmai standardokra egyaránt kevéssé reagáló voltának, azaz viszonylagos passzivitásának hátterében számos tényező állhat. Ezek egyike lehet az, hogy a prevenciós tevékenységekkel kapcsolatos iskolai döntések általában nem tartoztak a magasan priorizált iskolai döntések közé (Paksi-Felvinczi-Schmidt 2011). Kutatási adatok azt is jelezték, hogy a nem közvetlen tudásátadáshoz kapcsolódó, inkább nevelési jellegü feladatok mint amilyen a prevenciós tevékenység is - jelen vannak ugyan a pedagógusi szerepelvárások között a szakma gondolkodásában, a tudásátadáshoz közvetlenül kapcsolódó feladatokhoz képest azonban ezek kevésbé hangsúlyosak, egyértelműek. E feladatoknak szerepelvárásokban megmutatkozó, viszonylagos háttérbe szorulása megjelent a szerepek gyakorlása során, azaz a tényleges pedagógusi munkában is (Paksi 2010; PaksiFelvinczi-Schmidt 2011).

Amennyiben az iskola prevenciós tevékenységét inkább egyfajta a prevenciós szolgáltatásokat lekövető s a pénzügyi és szakmai támogatásokra érzékeny tevékenységnek tekintjük, akkor az iskolák prevenciós aktivitásának időbeni változása kapcsán érdemes az ezekkel a jelenségekkel kapcsolatos tapasztalatokat is röviden áttekinteni. Erre vonatkozó információink a drogprevenció területéről származnak. A 2015-ben, illetve a 2017-ben készült kvalitatív kutatások (KCKT 2015, 2018) alapján az alábbi főbb tényezők azonosíthatók a prevenció alacsony és egyre csökkenő hozzáférhetőségének hátterében: 
I. Információhiány, ami miatt a meglévő lehetőségek, szolgáltatások sem jutnak el a célcsoporthoz: $:^{16}$

„...egyáltalán az iskola hogy találja meg ezeket a programokat?” (részlet egy 2015-ös fókuszcsoportból)

„Szájhagyomány útján terjed, hát hogy ennek segitettem, annak segitettem, hogy akkor jöjjön be ide..." (részlet egy 2017-es fókuszcsoportból)

\section{Forráshiány:}

„...az iskolák szivesen ... fogadnának be programokat, de rettentöen szükösek az ö kereteik..." (részlet egy 2015-ös fókuszcsoportból)

III. Nem az iskola kezében van a döntés:

„Ugye korábban ... az iskolák is tudtak pályázatot benyújtani. Nálunk most például konkrétan a térségben problémaként jelenik meg, hogy iskola önállóan nem tud benyújtani pályázatot, még akkor sem, hogyha szakmai szervezettel együttmüködésben tenné ezt, és esetleg még OEFI ajánlás is van. Mert, hogy létrehozták a Klebelsberg Intézetet, és innentöl kezdve megjelennek ezek a problémák, hogy akkor most ki lesz a kompetens, az iskola igazgatója vagy a tankerület vezetöje, vagy ki merre lépjen, ki fizeti a révészt." (részlet egy 2015-ös fókuszcsoportból)

\section{A prevenciós programok ajánlási rendszere: ${ }^{17}$}

...végül is elösegíteni szeretné a minöségét, jelen esetben hátráltatja, mert egy csomó pályázat azért nem kapott pénzt, mert nincs meg az a bizonyos... Amelyiknek megvan, az meg annyira kevés .... hogy ők, ha akarnák, se tudnák csak az országnak egy minimális, nem látható, szabad szemmel nem látható részét lefedni." (részlet egy 2015-ös fókuszcsoportból) „.... kevés az a meritési közeg, amiböl tudunk választani szakmai programot ..., azok a szakmai civil szervezetek, akik nagyon széles palettával rendelkeznek, és tudnák kinálni a prevenciós programokat az ifjúság számára, azok valamiért nem tudnak oda bejutni..." (részlet egy 2017-es fókuszcsoportból)

16 Az iskolák prevenciós aktivitásának második, minőségi fejlődést is hozó periódusában készült ez idáig az egyetlen, a programok nemzetközi standardoknak megfelelö, szisztematikus leírását adó, számos keresési algoritmussal ellátott prevenciós adattár (Paksi-Demetrovics 2005), mely 234 iskolai prevenciós programról szolgált részletes információkkal. Ugyanebben az időszakban került kialakításra a Szakmai Információs Portál (SZIP) is. Az utóbbi közel egy évtizedben ezek a kataszterek nem kerültek frissítésre, az elmúlt évben (a KCKT kutatásait követően) történt próbálkozás az információs deficit kezelésére, a Nemzeti Drog Fókuszpont gondozásában létrejött a https://ellataskereso.hu/, melyen jelenleg 137 drogprevenciós szolgáltatás található. [Letöltve: 2019.09.01.]

17 „A nevelési-oktatási intézmény saját pedagógus-munkakörben foglalkoztatott alkalmazottján és az intézményben iskola-egészségügyi szolgálatot ellátó szakemberen kívül csak olyan, a nevelési-oktatási intézménnyel jogviszonyban nem álló szakembert vagy szervezet programját megvalósító személyt vonhat be tanórai vagy gyermek, tanuló részére szervezett egyéb foglalkozás vagy egyéb egészségfejlesztési és prevenciós tevékenység megszervezésébe, aki vagy amely rendelkezik az egészségügyért felelős miniszter által kijelölt intézmény szakmai ajánlásával." 20/2012. (VII. 31.) EMMI rendelet. https://net.jogtar.hu/ jogszabaly?docid=A1200020.EMM

Az ajánlások kiadását az OEFI 2013. február 1-től indította el, amit később a NEFI, majd 2017 áprilisától az ajánlási rendszer müködtetését az EMMI (az intézet jogutódja) vette át.

Az aktuális ajánlást kiadni jogosult szervezet által egy-egy évben kiadott ajánlások száma mindvégig nagyon alacsony volt. Pl. 2013-ban 17, 2014-ben 11, 2015-ben 9. http://drogfokuszpont.hu/eves-jelentesek/.Összehasonlításként, 2004-ben 280 prevenciós program szerepelt az iskolai prevenciós programkínálatban. 


\section{Szakemberhiány:}

„.. minket többször megkerestek BRFK-s prevenciót tartó kollegák, akik arra kértek minket, hogy menjünk el és tartsuk meg, mert nekik el kell menniük oda, de nem tudják, bogy amúgy mit tarthatnának meg" (részlet egy 2017-es fókuszcsoportból)

VI. Módszertani és/vagy szakmapolitikai támogatás hiánya: „semmi támogatás ... se módszertani, se szakmapolitikai támogatottság”" (részlet egy 2017es fókuszcsoportból)

A fentiek mellett - vagy inkább helyett - egy ideális prevenciós rendszerben a beavatkozások hozzáférhetőségét döntően a célpopulációban azonosítható szükségletek, tartalmát pedig szakmai/tudományos ajánlások, bizonyítékon alapuló beavatkozások határozzák meg. A bemutatott változások ilyen kontextusban történő vizsgálata túlmegy a tanulmány keretein, azonban a lapszám több írása támpontot adhat ezeknek a szempontoknak a továbbgondolásához.

\section{IRODALOM}

Balázs J. \& Sajgál R. (1998) Középiskolások értékorientációi. Educatio, Vol. 7. No. 3. (Mentálhigiéné) pp. 316-326.

Bradshaw, J. R. (1972) The Taxonomy of Social Need. In: G. McLachlan (ed.) Problems and Progress in Medical Care. Oxford, Oxford University Press. pp. 71-82.

Brotherhood, A. \& Sumnall, H. R. (2011) European Drug Prevention Quality Standards. EMCDDA, Lisbon. Fordítás: Nemzeti Drog Fókuszpont, 2012. http://drogfokuszpont. hu/wp-content/uploads/prevencios_minosegi_standardok_HU.pdf [Letöltve: 2019. 09. 01.]

Caplan, G. (1964) Principles of Preventive Psychiatry. New York, Basic Books.

Dusenbury, L. \& Falco, M. (1995) Eleven Components of Effective Drug Abuse Prevention Curricula. Journal of School Health, Vol. 65. No. 10. pp. 420-425.

Elekes Zs. (2019) Szerfogyasztás rizikótényezői középiskolások körében. Educatio, Vol. 28. No. 3. Lásd jelen füzetünkben: pp. 495-511.

Elekes Zs. \& Paksi B. (1996) A magyarországi középiskolások alkohol és drogfogyasztása. ESPAD, The European School Survey Project on Alcohol and Drugs, 1995. Budapest, Népjóléti Minisztérium.

Elekes Zs. \& PAKsi B. (2000) Drogok és fiatalok. Középiskolások droghasználata, alkoholfogyasztása és dohányzása az évezred végén, Magyarországon. (ISMertető 8.) Budapest, ISM.

EMCDDA (2005) Annual Report 2005: The State of the Drugs Problem in Europe. Belgium, Office for Official Publications of the European Communities.

EMCDDA (2008) Annual Report 2008: The State of the Drugs Problem in Europe. Luxembourg, Office for Official Publications of the European Communities.

EMCDDA (2015) Prevention Profiles 2015. Online Publication. Lisbon, European Monitoring Centre for Drugs and Drug Addiction. Hozzáférhető: http://www.emcdda.europa. eu/countries/prevention-profiles/about [Letöltve: 2019. 09. 01.]

Felvinczi K. (1998) A mentálhigiéné és az egészségmegőrzés lehetőségei a közoktatásban. Iskolakultúra, 1998. május, pp.17-31. 
Felvinczi K. (2009) A kábítószer-probléma kezelésével összefüggő prevenciós tevékenység. In: Felvinzi K. \& Nyírády A. (eds) Drogpolitika számokban. Budapest, L'Harmattan.

Flay, B. R. (2000) Approaches to Substance Use Prevention Utilising School Curriculum Plus Social Environment Change. Addictive Behaviours, Vol. 25. No. 6. pp. 861-885.

Gee, R. L., Espiritu, R. C. \& Huang, L. N. (2006) Adolescents with Cooccurring Mental Health and Substance Use Disorders in Primary Care. Adolescent Medicine Clinics, Vol. 17. No. 2. pp. 427-452.

Hansen, W. (1992) School-based Substance Abuse Prevention: A Review of the State of the Art in Curriculum, 1980-1990. Health Education Research, Vol. 7. No. 3. pp. 403430.

KCKT (2015) Élö Jelentés - a magyarországi droghelyzetröl. Budapest, Kábítószerügyi Civil Koordinációs Testület. https://web.archive.org/web/20170419192442/http://madaszsz. hu/norveg_doksi/kckt/elo_jelentes_1015.pdf [Letöltve: 2019.09. 01.]

KCKT (2018) A Nemzeti Drogellenes Stratégia végrehajtásának félidös értékelése - A kábitószerügy területén dolgozó szervezetek és szakemberek percepciói alapján. Budapest, Kábítószerügyi Civil Koordinációs Testület. https://docs.wixstatic.com/ugd/178071_4c5fac2f3 bf140e6918fff8fd77b179f.pdf [Letöltve: 2019. 09. 01.]

Mrazek, P. J. \& Haggerty, R. J. (1994, eds) Reducing Risks for Mental Disorders: Frontiers for Preventive Intervention Research. Washington DC, Institute of Medicine, National Academy Press.

NDS (2013) Nemzeti Drogellenes Stratégia 2013-2020 - Tiszta tudat, józanság, küzdelem a kábitószer-bünözés ellen. Melléklet a 80/2013. (X.16.) OGY határozathoz. https://mkogy. jogtar.hu/jogszabaly?docid=A13H0080.OGY [Letöltve: 2019. 09. 01.]

Németh Á., Horváth Zs. \& VÁrnai D. (2019) Egészségmagatartás serdülőkorban Mi történt az ezredforduló óta? Educatio, Vol. 28. No. 3. Lásd jelen füzetünkben: pp. 473494.

Paglia, A. \& Room, R. (1999) Preventing Substance Use Problems among Youth: A Literature Review and Recommendations. Journal of Primary Prevention, Vol. 20. No. 1. pp. 3-50.

PAKsi B. (2010) A közoktatási intézmények prevenciós kompetenciáinak és tevékenységének változásai az utóbbi 5 évben. Addiktológia, Vol. 8. No. 3. pp. 185-215.

Paksi B. \& Demetrovics Zs. (2005) Országos Drogprevenciós Adattár. Budapest, L’Harmattan Kiadó.

Paksi B., Felvinczi K. \& Schmidt A. (2011) Az iskolák prevenciós aktivitása. In: Paksi B. \& Demetrovics Zs. (eds) Drogprevenció és egészségfejlesztés az iskolában. Budapest, NDI. L'Harmattan. pp. 95-170.

Paksi B. \& Magi A. (2013) Drogprevenciós helyzet(jelentés) - kvalitatív kutatás a területen dolgozó szakmai szolgáltatók körében. socio.hu. Az MTA Társadalomtudományi Kutatóközpont Szociológiai Intézet online folyóirata. 2013/2. https:/socio.hu/uploads/ files/2013_2/1paksi_magi.pdf [Letöltve: 2019.09.01.]

Paksi B., Magi A. \& Demetrovics Zs. (2017) A függőségek, mint a kirekesztés szempontjából leginkább veszélyeztető magatartások interveniálása az iskolában - a szenvedélymagatartásokra irányuló iskolai prevenciós beavatkozások országos katasztere. In: Kerülő J., Jenei T., \& Gyarmati I. (eds) XVII. Országos Neveléstudományi Konferencia. Program és absztrakt kötet. MTA. Nyíregyházi Egyetem, p. 482.

Perjés I. \& Kovács Z. (2002) Az iskola külső és belső világának interdiszciplináris vizsgálata. In: Perjés I. \& Kovács Z. (eds) Életvilágok találkozása. Aula Kiadó, Budapest. pp. 35-57. 
Reis, J., Riley, W., Lokman, L. \& Baer, J. (2000) Interactive Multimedia Preventive Alcohol Education: A Technology Application in Higher Education. Journal of Drug Education, Vol. 30. No. 4. pp. 399-421.

Robertson, E. B., David, S. L. \& Rao, S. A. (2003) Preventing Drug Use among Children and Adolescents: A Research-based Guide for Parents, Educators, and Community Leaders. National Institute on Drug Abuse. Second Edition, NIH Publication No. 04-4212(A).

Robinson, J., Haaz, E., Petrica, S., Hillsberg, B. \& Kennedy, N. (2004) Managed Care and Prevention of Mental Health and Substance Abuse Problems: Opportunities for Growth through Collaboration in the New Millenium. Journal of Primary Prevention, Vol. 24. No. 3. pp. 353-373.

Siegel, M. \& Bieger, M. (2000) The Impact of an Antismoking Media Campaign on Progression to Established Smoking: Results of a Longitudinal Youth Study. American Journal of Public Health, Vol. 90. No. 3. pp. 380-386.

Simony I. (2012) Az egészségfejlesztés helyzete a hazai nevelési-oktatási intézményekben. In: Darvay S. (ed.) Tanulmányok a gyermekkori egészségfejlesztés témaköréböl. Budapest, Eötvös Loránd Tudományegyetem. pp. 9-21.

Soole, D. W., Mazerolle, L. \& Rombouts, S. (2005) School Based Drug Prevention: A Systematic Review of the Effectiveness on Illicit Drug Use. The Drug Policy Modelling Project Monograph Series. Fitzroy, Turning Point Alcohol and Drug Centre.

Taylor, B. J. (2000) Modeling Prevention Program Effects on Growth in Substance Use: Analysis of Five Years of Data from the Adolescent Alcohol Prevention Trial. Prevention Science, Vol. 1. No. 4. pp. 183-97.

Tobler, N. S. (1997) Meta-Analysis of Adolescent Drug Prevention Programs: Results of the 1933 Meta-analysis. In: W. J. Bukovski (ed.) Meta-analysis of Drug Abuse Prevention Programs. NIDA Research Monograph, Number 170. Wshington, US Department of Health and Human Services. National Institute of Health. pp. 5-68.

Tobler, N. (2001) Prevention Is a Two-way Process. Drug and Alcohol Findings, Issue 5. pp. 25-27.

Tobler, N. S., Roona, M. R. \& Ochshorn, P. (2000) School-based Adolescent Prevention Programs: 1998 Meta-analysis. Journal of Primary Prevention, Vol. 20. No. 4. pp. 275336.

Tobler, N. S. \& Stratton, H. H. (1997) Effectiveness of School-based Drug Prevention Programs: A Meta-analysis of the Research. Journal of Primary Prevention, Vol. 18. No. 1. pp. 1-128.

Werch, C. E. \& Owen, D. M. (2002) Iatrogenic Effects of Alcohol and Drug Prevention Programs. Journal of Studies on Alcohol, Vol. 63. No. 5. pp. 581-90.

A cikk a Creative Commons Attribution 4.0 International License (https://creativecommons.org/licenses/ by/4.0/) feltételei szerint publikált Open Access közlemény, melynek szellemében a cikk bármilyen médiumban szabadon felhasználható, megosztható és újraközölhető, feltéve, hogy az eredeti szerző és a közlés helye, illetve a CC License linkje és az esetlegesen végrehajtott módosítások feltüntetésre kerülnek. (SID_1) 